\title{
Utilization of Melamine Impregnated Paper Waste as a Filler in Thermoplastic Composites
}

\author{
Fatma Bozkurt, ${ }^{\mathrm{a}, *}$ Büşra Avci, ${ }^{\mathrm{a}}$ and Fatih Mengeloğlu ${ }^{\mathrm{a}, \mathrm{b}}$ \\ The potential utilization of melamine impregnated paper (MIP) waste in \\ thermoplastic composites was investigated. Composites were also \\ manufactured utilizing wood flour (WF) at the same filler rates for \\ comparison. The composites were manufactured using a compression \\ molding method. The effects of filler type and filler rate on the mechanical \\ properties of low-density polyethylene (LDPE)-based composites were \\ evaluated. Mechanical properties, such as tensile and flexural strengths, \\ were determined in accordance with ASTM D638 (2001) and ASTM D790 \\ (2003), respectively. Results showed that filler type and filler content had \\ significant effects on all mechanical properties investigated. Both fillers \\ improved all mechanical properties except for tensile strength and \\ elongation at break of LDPE. In conclusion, MIP waste has a potential to \\ be utilized in thermoplastic-based composite manufacturing and might \\ generate some economic and environmental benefits.
}

Keywords: Waste melamine impregnated paper; Thermoplastic; Composite; Mechanical properties

Contact information: a: Department of Forest Industry Engineering, Kahramanmaras Sutcu Imam University, Kahramanmaras, Turkey; b: Department of Materials Science and Engineering, Graduate School of Natural and Applied Sciences, Kahramanmaras Sutcu Imam University, Kahramanmaras, Turkey; *Corresponding author: bozkurtfatima@ gmail.com

\section{INTRODUCTION}

The global utilization of wood-based panels has increased tremendously. Growing population, development of the construction sector, and need for new furniture have played an important role in this increase. Over the years, customers' expectations from furniture have evolved, and a variety of products at affordable price is vital. Application of new coating techniques, films, thin veneers, pattern printing, and lacquer paints on the surface of wood-based panels has provided a number of choices for the manufacturer. These materials provided good aesthetic appearance and improved properties. Melamine impregnated paper (MIP) is the most preferred coating materials used in wood-based panel sector due to its advantages such as resistance to chemicals, fungi, insects, heat, water/moisture, high wear, homogeneous structure, low formaldehyde emission, color stability, etc. (Nemli 2003a; Aksu 2009).

Several studies have been conducted to evaluate the effect of MIP coating on surfaces and on the various board properties. Their effect on mechanical properties (Lee and Kim 1985; Chow et al. 1996; Nemli 2000; Bektaş et al. 2002; Nemli et al. 2005a), physical properties (Nemli 2000; Bektaş et al. 2002), formaldehyde emissions (Nemli 2000; Nemli and ve Çolakoğlu 2005; Wang et al. 2007; Liu and Zhu 2014), and resistance to heat, light, and chemicals were investigated and improved performances were reported.

Turkey is a major producer of medium-density fiberboard (MDF) and particleboard. The total annual capacity of the sector is $11,517,120 \mathrm{~m}^{3}$; of which $5,545,920$ 
$\mathrm{m}^{3}$ is particleboard and 5,971,200 $\mathrm{m}^{3}$ is fiberboard (MDF) (Özmen et al. 2014; İstek et al. 2017). Approximately $94 \%$ of all manufactured panels are MIP-coated. It was reported that annual MIP utilization of Kastamonu Integrated Wood Industry (KEAS) and Starwood Forest Products Inc. were around 420,000,000 and 80,000,000 $\mathrm{m}^{2}$, respectively. The MIP wastes (approximately 0.6\%) are generated either during melamine impregnation line (MIP production) or during coating of the MIP on panel surfaces (MIP pressing section). A large portion of the wastes are generated in the melamine impregnation line. These MIPs contain approximately $52 \%$ to $53 \%$ adhesive (urea, melamine formaldehyde), $40 \%$ alpha-cellulose paper, and $7 \%$ to $8 \%$ other chemicals, such as separator, anti-dust, anti-block, etc. (Barbu and Steinwender 2009). It is reported that KEAS generates approximately 15,210,000 $\mathrm{m}^{2} /$ year $(2,737,800 \mathrm{~kg})$ MIP wastes. Waste MIPs are not suitable for generating energy through direct combustion due to the chemicals they contain (Mengeloglu et al. 2015). Special boilers resistant to high temperature and pressure are also needed (Barbu and Steinwender 2009). Landfilling of MIP wastes is also not viable option because it costs extra and poses some environmental risks. Additionally, it leads to loss of a potential raw material. It is believed that utilization of MIP waste in manufacturing might avoid the environmental pollution and contribute to the economy.

Several studies have been conducted on the potential utilization of MIP waste in composites. Varga et al. (2004) used a mixture of urea formaldehyde (UF) and waste MIP at various ratios as an adhesive during particleboard manufacturing. It was stated that modulus of rupture (MOR), internal bond (IB), and formaldehyde emission properties of the manufactured particleboards satisfied the requirements of related standards. It was concluded that the addition of waste MIP made it possible to utilize less adhesive in particleboard- manufacturing with improved or similar properties to UF bonded particleboard. In another study, Fur et al. (2004) utilized MIP wastes in particleboard manufacturing. They were either added directly to the particle furnish as a powder form or used as a melamine substitute during in melamine-urea formaldehyde (MUF) resin preparation. It was concluded that particleboard were successfully produced with both methods. Alpar and Winkler (2006) also investigated the potential utilization of 5\%, 10\%, and $20 \%$ additions of MIP waste (powder form) as adhesive replacement in particleboard production. Without using additional adhesive, the particleboards with acceptable properties were produced with the $20 \%$ MIP waste utilization. In another study, Basboğa et al. (2017) utilized 10\% and 15\% MIP wastes (coming from MIP production section and from MIP pressing section) as an adhesive replacement in particleboard manufacturing. Waste types were used both alone and as a 1:1 mixture of the two. The particleboard produced with both $10 \%$ and $15 \%$ first type-MIP wastes loading (MIP manufacturing) provided mechanical properties exceeding standard values. It was concluded that this type of MIP waste can be utilized in particleboard manufacturing as an adhesive replacement. Basboğa et al. (2018) also investigated the effectiveness of MIP wastes in particleboard manufacturing. For this purpose, they produced particleboard using both MIP wastes (powder) and neat resin (used in impregnation process) separately as an adhesive. A study conducted by Basboğa et al. (2018) showed that MIP wastes can be effectively used as an adhesive replacement in particleboard manufacturing.

The MIP wastes are also utilized as a filling material in various composite products. Silva et al. (2012) utilized MIP wastes as a wood particle replacement in medium-density particleboard. Approximately 4\%, 8\%, and 12\% MIP wastes were first mixed with 92\%, $96 \%$, and $88 \%$ wood particles, respectively and then this mixture was used in core layer of particleboard. In the study, a fixed amount of adhesive was used throughout. With the 
exception of $12 \%$ MIP wastes addition, the other particleboards provided properties that met Brazilian standards. In contrast, Çavdar et al. (2013) used waste MIPs (10\%, 20\%, $30 \%, 40 \%$, and $50 \%$ ) as filling material in the core layer of oriented strand board (OSB) production and 14\% UF adhesive was used as a binder. It was determined that the use of waste MIPs positively affected the mechanical and physical properties. In another study, Ayrilmis (2012) evaluated the usage of waste MIPs in the production of light MDF manufacturing. Amounts of 5\%, 10\%, and 20\% MIP wastes (overlay and decorative paper) were blended with wood fibers with $11 \%$ UF resin. Dimensional stability and mechanical properties of the resulting MDF products were improved because of the addition of waste paper into the formulations.

Utilization of MIP wastes in thermoplastic materials was also reported by Mengeloğlu et al. (2015). They produced thermoset composites with MIP wastes (without using any additional adhesives) and thermoplastic composites using 1:1 mixture of MIP wastes and low-density polyethylene (LDPE). Thermoset composites provided higher strength and modulus values for tensile and flexural modulus tests compared to thermoplastic composites. However, only one mixture for thermoplastic composite was studied.

Previous studies showed that MIP wastes have a great potential to be utilized not only as an adhesive replacement but also as a filling material in particleboard and other wood-based boards production. However, the MIP wastes performance in thermoplastic composites at various filling concentrations has not been investigated thoroughly. In this study, the effects of MIP waste contents on some physical and mechanical properties of LDPE-based thermoplastic composites were determined and their performance was also compared with the wood flour filled-LDPE based thermoplastic composites.

\section{EXPERIMENTAL}

\section{Materials}

In this work teak wood flour (WF) obtained from wood saw dust in Kahramanmaraş (Turkey) were used as lignocellulosic filler material. The saw dust was ground into flour form using a Wiley mill (Altundal; Kahramanmaraş, Turkey). The MIP were kindly donated by Kastamonu Entegre, MDF Plant, Adana, Turkey. The WF and MIP particles that passed through 40-mesh and remained on a 60-mesh screen $(0.25 \mathrm{~mm}$ and $250 \mu \mathrm{m}$, respectively) were used after drying for $24 \mathrm{~h}$ at the temperature of $103 \pm 2{ }^{\circ} \mathrm{C}$. The LDPE (F2-12) polymeric matrix was purchased from Petkim Petrochemical Co. (Izmir, Turkey).

\section{Composite Manufacturing}

Composite materials were produced using a compression molding method. The manufacturing plan is given in Table 1. According to manufacturing procedure; lignocellulosic fillers and LDPE were first mixed in a mixer $(\approx 1000 \mathrm{rpm}$ for $5 \mathrm{~s})$ to obtain a homogeneous blend and then this mixture was compression molded into $4 \mathrm{~mm} \times 160 \mathrm{~mm}$ $\times 160 \mathrm{~mm}$ size mold (Carver Press) at $185^{\circ} \mathrm{C}$ press temperature and at 1.0 bar $\left(10\right.$ tons $\left./ \mathrm{m}^{2}\right)$ press pressure for $10 \mathrm{~min}$.

Test specimens were conditioned at a relative humidity of $65 \% \pm 5 \%$ and a temperature of $23 \pm 2{ }^{\circ} \mathrm{C}$. The density was determined by a water displacement technique according to the ASTM D792 (2007) standard. Flexural, tensile, and hardness of all specimens were determined according to ASTM D790 (2003), ASTM D638 (2001), and 
ASTM D2240 (2010), respectively. Flexural and tensile tests were implemented on a Zwick $10 \mathrm{KN}$ (Ulm, Germany) machine. Morphological properties of samples were analyzed using scanning electron microscopy (SEM), (EVO LS10; Carl Zeiss, Jena, Germany). For this analysis, the samples were dipped into liquid nitrogen and snapped in half to attain clean surfaces. The specimens were then placed on a specimen holder and sputtered with gold (Sputter Coater 108 Auto; Cressington, London, England) to prevent charge accumulation of the electron absorbed by the specimens with $10 \mathrm{~mA}$ in $120 \mathrm{~s}$. For statistical analysis, Design-Expert ${ }^{\circledR}$ version 7.0.3 statistical software (Minneapolis, MN, USA) was used.

Table 1. Manufacturing Plan of Woof Plastic Composites

\begin{tabular}{|c|c|c|c|}
\hline Sample ID & LDPE (\%) & MIP (\%) & WF (\%) \\
\hline PE & 100 & 0 & 0 \\
\hline PE-25MIP & 75 & 25 & 0 \\
\hline PE-50MIP & 50 & 50 & 0 \\
\hline PE-75MIP & 25 & 75 & 0 \\
\hline PE-25WF & 75 & 0 & 25 \\
\hline PE-50WF & 50 & 0 & 50 \\
\hline PE-75WF & 25 & 0 & 75 \\
\hline
\end{tabular}

LDPE: Low-density polyethylene; MIP: Melamine impregnated paper; and WF: Wood flour

\section{RESULTS AND DISCUSSION}

Density values of the samples tested were in the range of 0.87 to $1.2 \mathrm{~g} / \mathrm{cm}^{3}$. The interaction graph showing the effects of filler type and ratio on the density of composites is presented in Fig. 1. Statistical analysis showed that the filler content and filler type had significant effect on density $(\mathrm{P}<0.0001)$. Composite densities were increased with the addition of lignocellulosic materials due to their higher cell wall densities. Similar results were also reported by others (Stokke et al. 2014; Karakuş and Mengeloğlu 2016; Çavuş and Mengeloğlu 2016; Mengeloğlu and Çavuş 2019). In the case of filler type, both MIP and WF as fillers increased the density of the composites, but at high filler levels, this increase was more pronounced for MIP filled ones (Fig. 1).

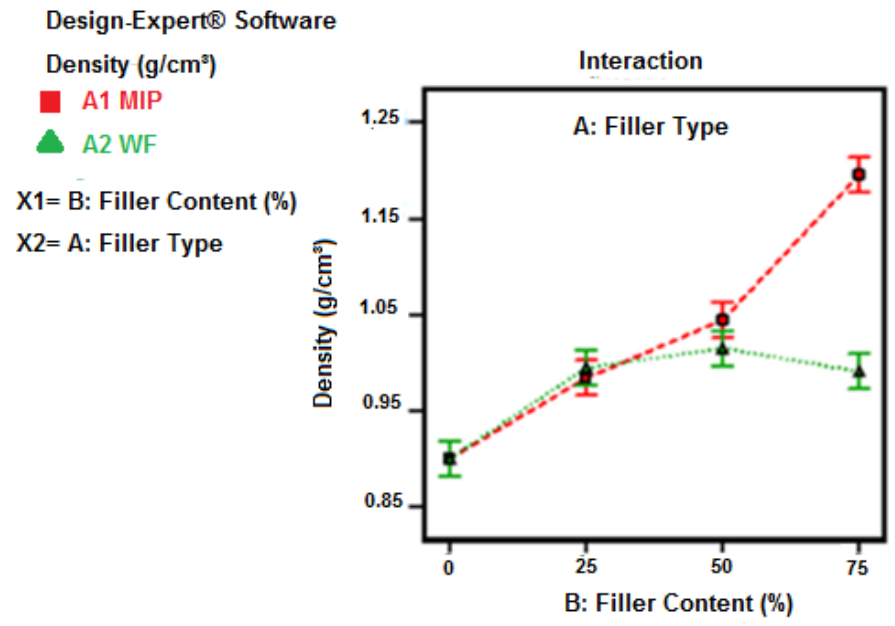

Fig. 1. The interaction graph of the density values of samples with filler type and content 
There are studies reporting that small particle size may provide increased composite densities because these small filler types may reduce the gap between filler and the polymer matrix (Çavdar 2011; Behazin et al. 2017; Chaudemanche et al. 2018). Because both filler types had similar particle sizes in this study (Figs. 2a and 2b), filler size might not be the possible reason for this difference. It is believed that the higher density of MIP filler might result in an increase in density because they are produced using cellulose fibers. Larger gaps were noticed between polymer and filler in composites having WF as filler (Figs. 2c and $2 \mathrm{~d}$ ). This might be the reason for the lower density of the composites having WF at high filler content levels.
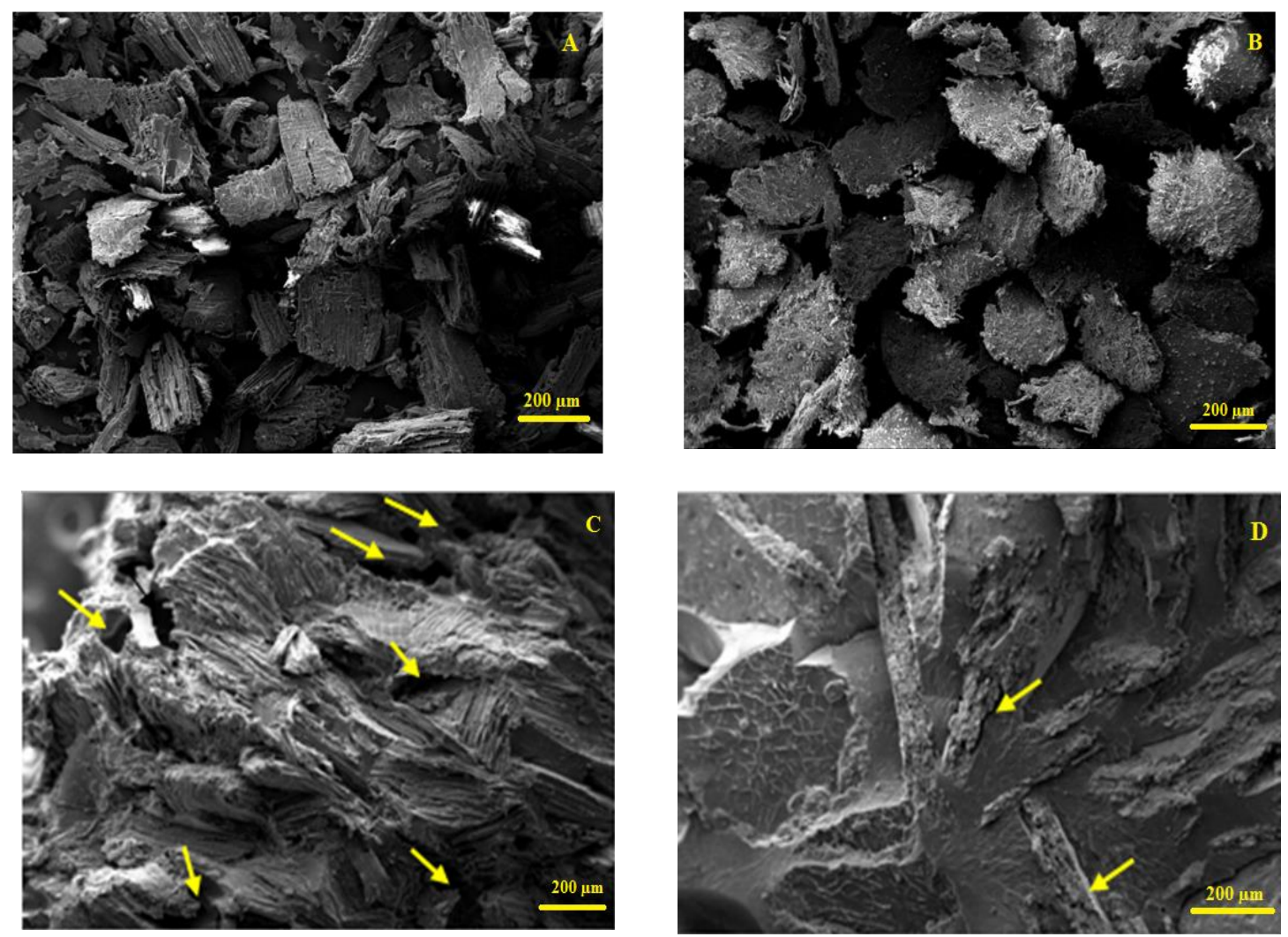

Fig. 2. SEM images of fillers and polymer composites: A) WF; B) MIP; C) PE-50WF; and D) PE50 MIP

Tensile strength (TS) values of the samples were in the range of 2.68 to $8.76 \mathrm{MPa}$. The interaction graph of TS is presented in Fig. 3. Statistical analysis showed that the filler proportional amounts and filler types had a significant effect on TS (P<0.0001). The TS values were reduced with increase of both MIP and WF contents (Fig. 2). Similar reduction of TS values with the increase in lignocellulosic filler ratio in polymer matrix was reported by others (Mengeloğlu ve Karakuş 2008). Plastic composites produced with coupling agent improved adhesion between hydrophilic (polar) fillers and hydrophobic (nonpolar) polymers. This result is consistent with previous studies (Poletto 2017; Cavus 2020).

Tensile modulus (TM) values of the samples were in the range of 95 to $484 \mathrm{MPa}$. The interaction graph of TM is presented in Fig. 4. Statistical analysis showed that the filler content and filler type had a significant effect on TM values $(\mathrm{P}<0.0001)$. Both filler type increased TM values, but it was more pronounced at high filler contents. The MIP and WF having higher cell wall density in the composite usually increased the modulus values of 
the resulting composites. This can be explained by the rule of mixtures (Matuana et al. 1998), meaning that there is a correlation between modulus values of composites and percentage and modulus values of its constituents. Increased TM values of lignocellulosic material-filled polymer composites were reported by other researchers (Rowel 2006; Mengeloğlu et al. 2015).

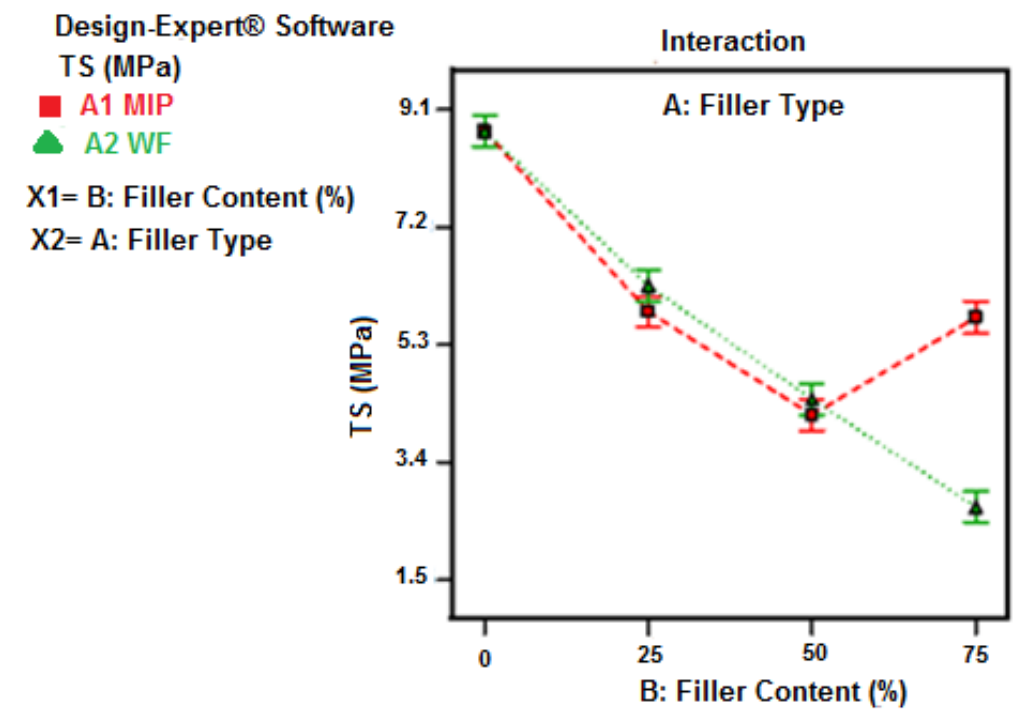

Fig. 3. The interaction graph of the tensile strength

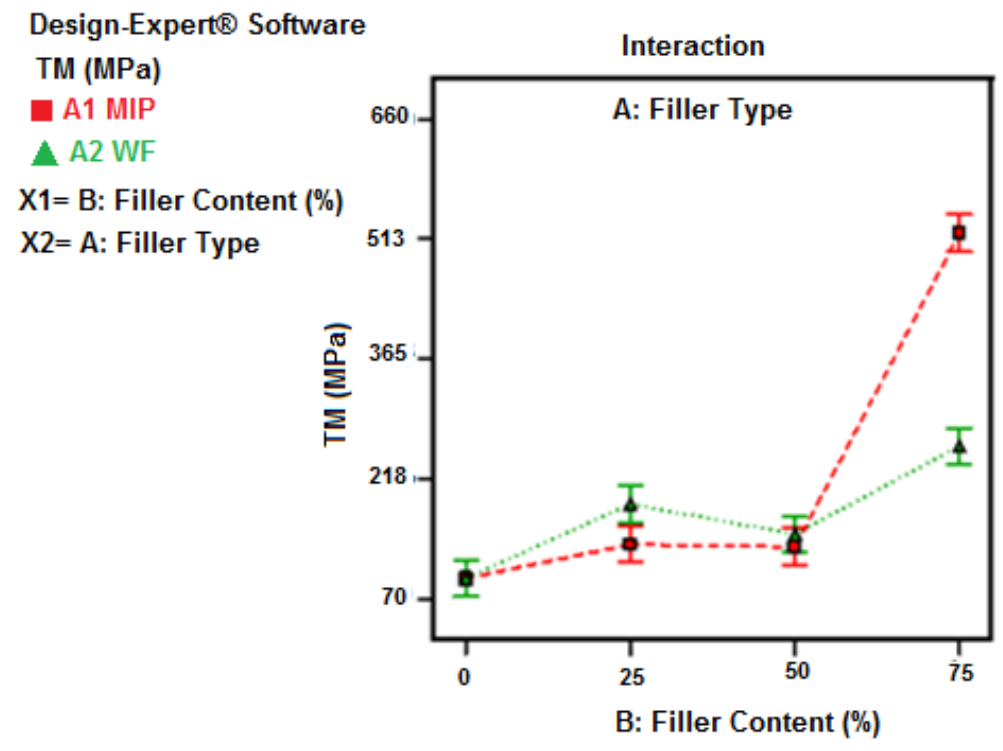

Fig. 4. The interaction graph of the tensile modulus

The elongation at break (EatB) values of the samples were in the range of $1.4 \%$ to $335 \%$. The interaction graph of EatB is presented in Fig. 5. Statistical analysis showed that the filler amounts had a significant effect on EatB $(\mathrm{P}<0.0001)$. There was also no significant difference noticed between filler types $(\mathrm{P}=0.907)$. Both filler types significantly reduced the EatB values of the composite samples. This reduction was a normal consequence of the increase in filler amount that limits the elongation of the 
samples (El-Shekeil et al.2012). Addition of the WF and MIP fibers as fillers led to a lower resistance to break. The EatB values usually decrease with the increase in modulus of the composites as reported for composites produced with various wood flours (Mengeloğlu and Karakuş 2008).

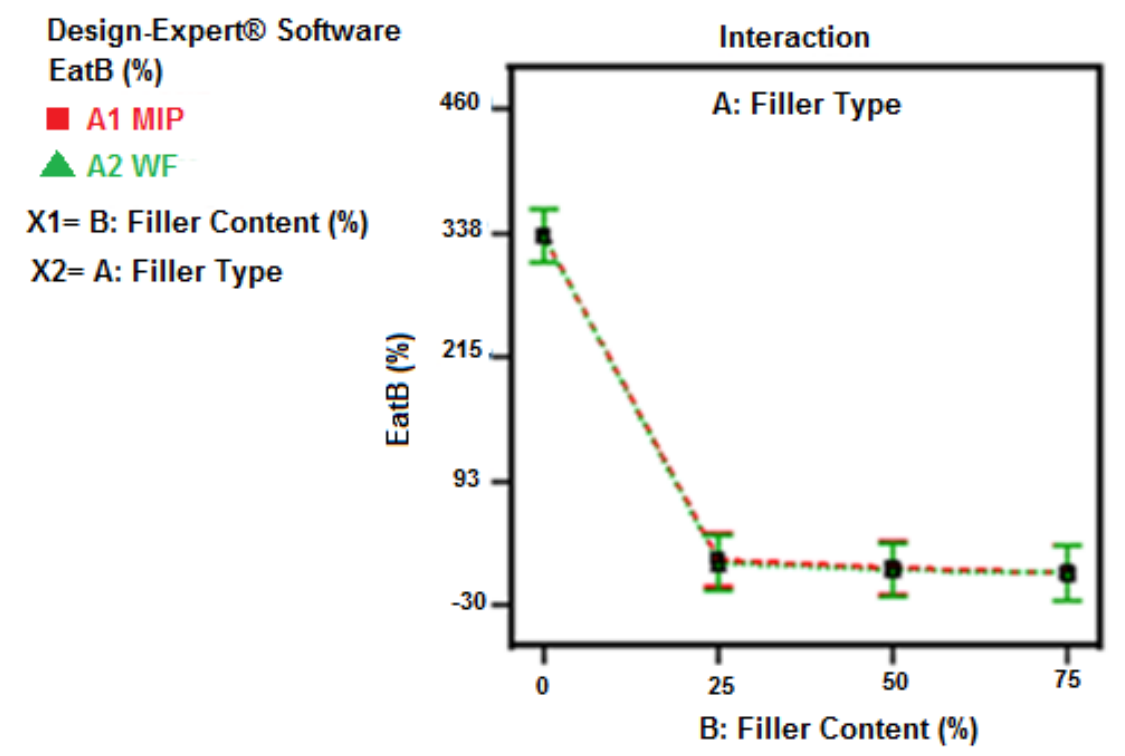

Fig. 5. The interaction graph of the elongation at break

Flexural strength (FS) values of the samples were in the range of 5.78 to $12.8 \mathrm{MPa}$. The interaction graph of FS is presented in Fig. 6. Statistical analysis showed that the filler content had a significant effect on FS $(\mathrm{P}<0.0001)$. There was also no significant difference noticed between two filler types $(\mathrm{P}=0.104)$. It has been found that the FS values in LDPE varied according to filler type. The FS values displayed similar properties with both WF and MIP participations as fillers. Similar results were reported by others (Mengeloğlu et al. 2015; Başboğa 2018; Afzaluddin et al. 2019).

The flexural modulus (FM) of the samples was in the range of 202 to $1235 \mathrm{MPa}$. The interaction graph of FM is presented in Fig. 7. Statistical analysis showed that the filler content $(\mathrm{P}<0.0002)$ and filler type $(\mathrm{P}<0.0001)$ had significant effects on FM. As the filler participation increased, the FM values also increased. Lignocellulosic fillers positively influenced the FM values, as has been reported (Varga et al. 2004; Alpar and Winkler 2006; Ayrılmış 2012; Çavdar 2013). It should be noted that 50\% and 75\% MIP and WFfilled composites provided FS and FM values of over $6.9 \mathrm{MPa}$ and $340 \mathrm{MPa}$, respectively. These results met the standard requirements of ASTM 6662-01 (2017) (requirements for polyolefin-based plastic lumber decking boards). 


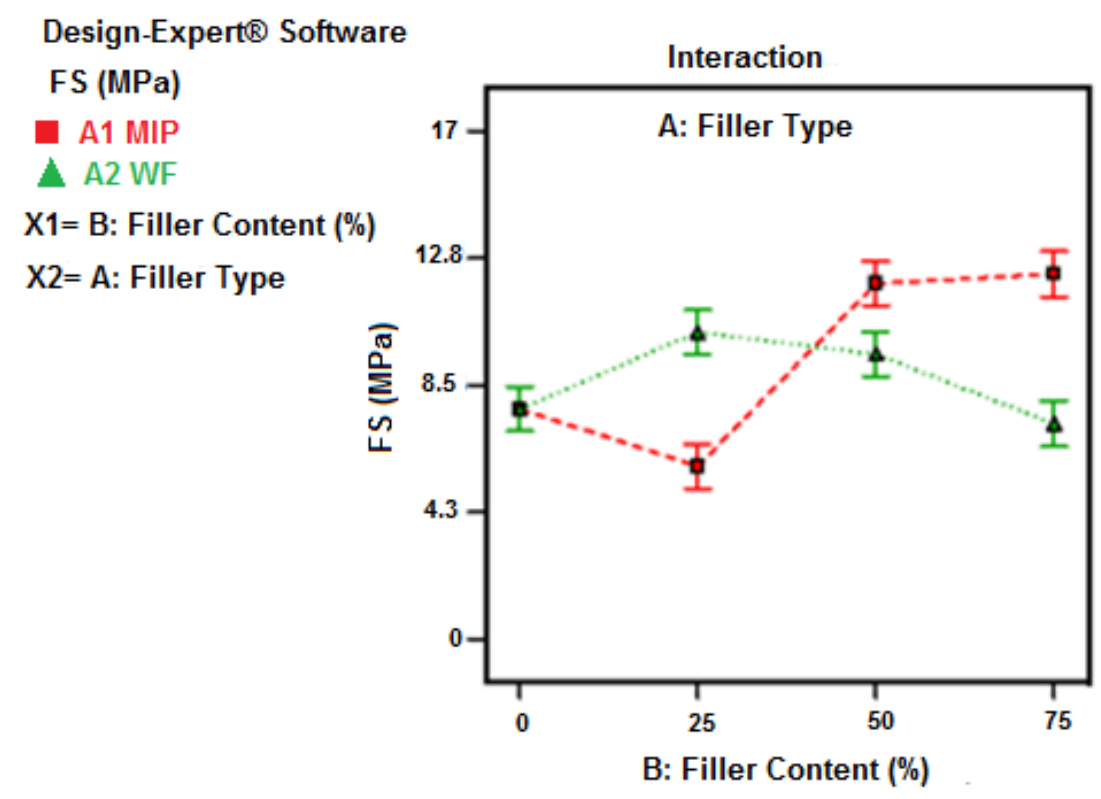

Fig. 6. The interaction graph of the flexural strength

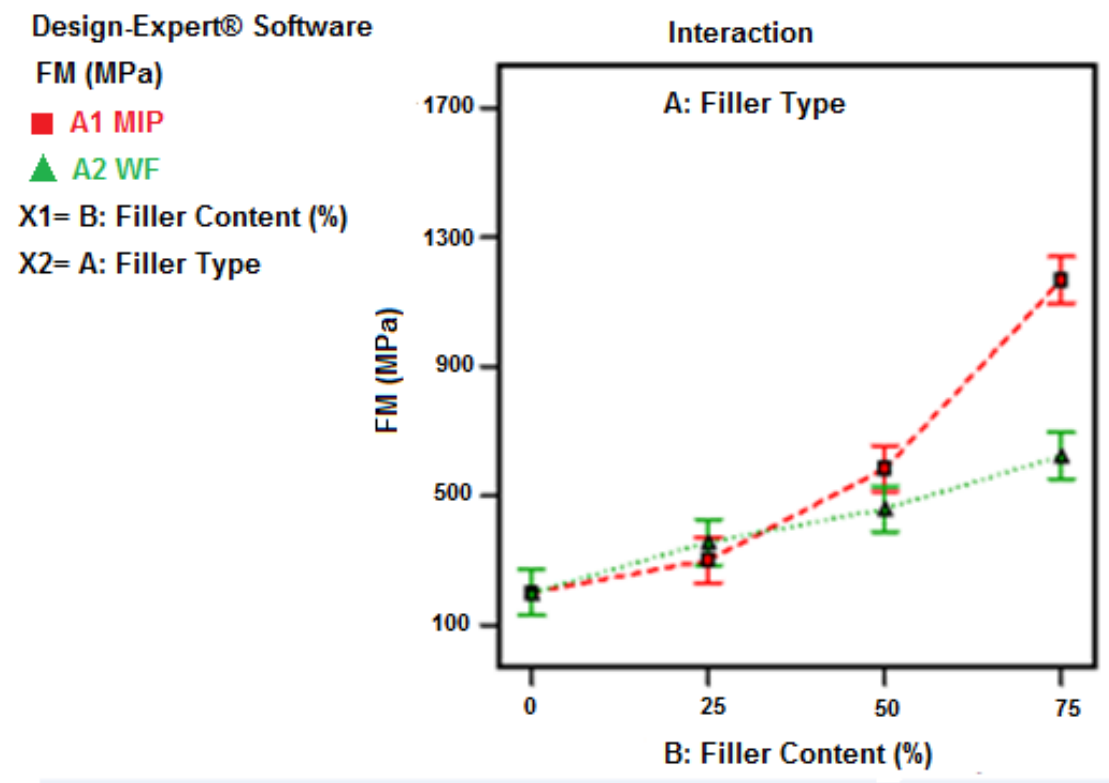

Fig. 7. The interaction graph of the flexural modulus

Hardness strength (Shore D) values of the samples were in the range of 47 and 65. The interaction graph of the hardness strength is presented in Fig. 8. Statistical analysis showed that the filler content had a significant effect on hardness strength $(\mathrm{P}<0.0001)$. There was also no significant difference observed between the two filler types $(P=0.750)$. Hardness values increased as filler participation rate increased in polymers composites. The WF or MIP fillers had a positive effect on Shore D values. Similar results of increased hardness and fragile matrix for filler incorporated polymeric matrix were also reported by others (Cavdar 2011; Karakuş ve Mengeloğlu 2016). Composites produced with 75\% filler provided hardness values considered as "extra hard material" (Shore D over 60), while the rest of the produced samples including neat polymer were measured as "hard material" (Shore D 30-60). 


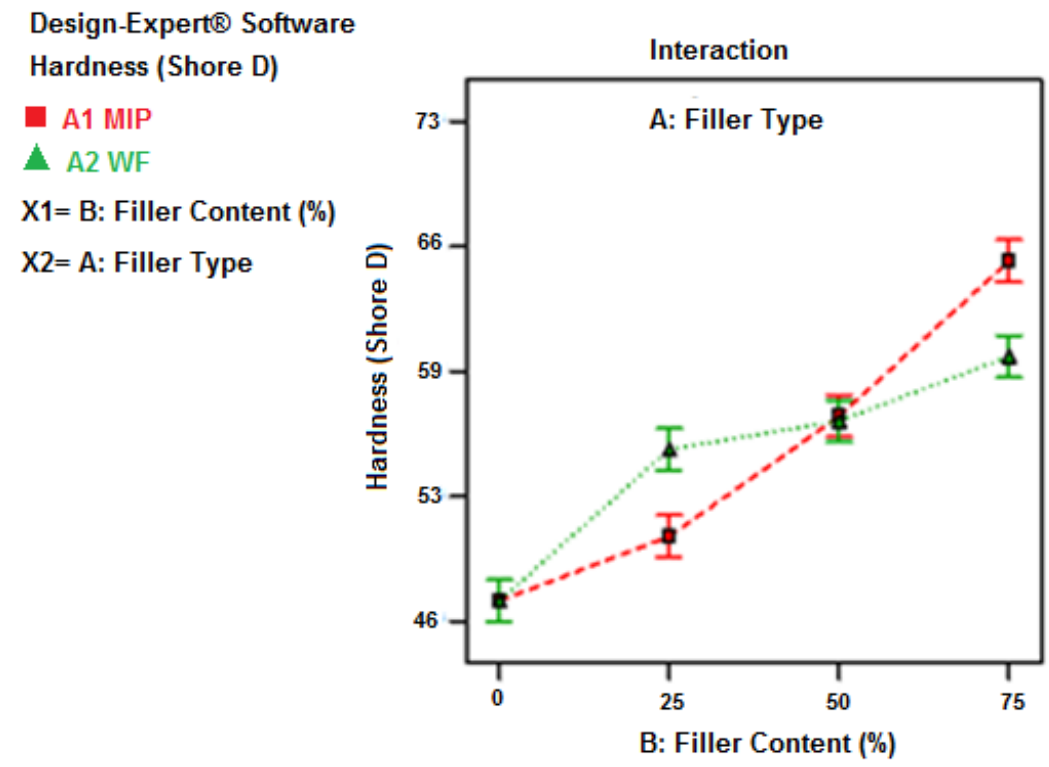

Fig. 8. The interaction graph of the hardness

\section{CONCLUSIONS}

In this study, low density polyethylene (LDPE)-based thermoplastic composites were produced using various amounts of wood flour (WF) and waste melamineimpregnated paper (MIP) as fillers at $25 \%, 50 \%$, and $75 \%$ content levels. The following conclusions were derived:

1. Both MIP wastes and WF can successfully be used as filling materials in thermoplasticbased composite production.

2. Addition of MIP wastes and WF in LDPE matrix increased the density of produced composites.

3. The thickness swelling (TS) values decreased with addition of MIP and WF up to 50\%. Further increase of MIP waste amounting to $75 \%$ resulted in an increase in composite strength values due to the increased density.

4. The composites with 50\% and 75\% MIP and WF as fillers provided FS and FM values that met the standard requirements of ASTM 6662-01 (2017) (6.9 and $340 \mathrm{MPa}$, respectively).

5. The MIP and WF fillers in LDPE adversely affected the elongation at break (EatB) of the composites produced. However, fillers positively affected the flexural modulus (FM) and hardness properties.

6. Addition of $75 \%$ filler in polymer matrix made the resulting composites "extra hard material" (Shore D over 60). 


\section{ACKNOWLEDGMENTS}

Authors would like to thank the Kastamonu Entegre, Adana MDF Facility for the donation of waste melamine impregnated paper (MIP) and particle.

\section{REFERENCES CITED}

Afzaluddin, A., Jawaid, M., Sapuan, S. M., and Ishak, M. (2019). "Physical and mechanical properties of sugar palm/glass fiber reinforced thermoplastic polyurethane hybrid composites," J. Mater. Res. Technol. 8(1), 950-959. DOI: 10.1016/j.jmrt.2018.04.024

Alpar, T., and Winkler, A. (2006). "Recycling of impregnated décor paper in particleboard," Acta Silv. Lign. Hung. 2006(2), 113-116.

ASTM D638. (2001). "Standard test methods for tensile properties of plastics," ASTM International, West Conshohocken, PA, USA.

ASTM D790. (2003). "Standard test methods for flexural properties of unreinforced and reinforced plastics and electrical insulating materials," ASTM International, West Conshohocken, PA, USA.

ASTM D792. (2007). "Standard test methods for density and specific gravity (relative density) of plastics by displacement," ASTM International, West Conshohocken, PA, USA.

ASTM D2240. (2010). "Standard test method for rubber property-durometer hardness," ASTM International, West Conshohocken, PA, USA.

ASTM 6662-01. (2017). "Standard specification for polyolefin-based plastic lumber decking boards," ASTM International, West Conshohocken, PA, USA.

Ayrılmış, N. (2012). "Enhancement of dimensional stability and mechanical properties of light MDF by adding melamine resin impregnated paper waste," Int. J. Adhes. Adhes. 33, 45-49. DOI: 10.1016/j.ijadhadh.2011.11.001

Barbu, M. C., and Steinwender, M. (2009). "The state of the art for the environmental protection in the European wood based panels industry," ProLigno 5(2), 85-96. DOI:

Başboğa, İ. H., Bozkurt, F., Atar, İ., and Mengeloğlu, F. (2017). "Different type of waste melamin impregnated paper (MIP) in particleboard manufacturing," ProLigno 13(1), 27-21. DOI:

Başboğa, İ. H. (2018). Utilization of Melamine Impregnated Paper Waste (MIP) in Particleboard Manufacturing, Ph.D. Thesis, Kahramanmaras Sutcu Imam University, Kahramanmaraş, Turkey.

Başboğa, İ. H., Atar, I., Karakuş, K., Yüce, Ö., and Mengeloğlu, F. (2018). "Effective of melamine impragnated paper (MIP) waste as an adhesive in particleboard manufacturing," Kastamonu Univ., Journal of Forestry Faculty 18 (3), 292-303. DOI: 10.17475/kastorman.498896

Behazin, E., Misra, M., and Mohanty, A. K. (2017). "Sustainable bio-composites from pyrolyzed grass and toughened polypropylene: Structure-property relationships," ACS Omega 2(5), 2191-2199. DOI: 10.1021/acsomega.7b00122

Bektaş, İ., Güler, C., and ve Kalaycioğlu, H. (2002). "Manufacturing of particleboard from sunflower stalks (Helianthus annuus L.) using urea-formaldehyde resin," Kahramanmaras Sutcu Imam University Journal of Engineering Sciences 5(2), 49-55. 
Chaudemanche, S., Perrot, A., Pimbert, S., Lecompte, T., and Faure, F. (2018). "Properties of an industrial extruded HDPE-WPC: The effect of the size distribution of wood flour particles," Constr. Build. Mater. 162, 543-552. DOI: 10.1016/j.conbuildmat.2017.12.061

Chow, P., Janowiak, J. J., and Price, E. W. (1996). "The internal bond and shear strength of hardwood veneered particleboard composites," Wood Fiber Sci. 18(1), 99-106.

Çavdar, A. D. (2011). Investigation of the Properties of Wood-Plastic Composites Produced from Several Lignocellulosic Filler and Thermoplastic Polymers, Ph.D. Dissertation, Karadeniz Technical University, Trabzon, Turkey.

Çavdar, A. D., Yel, H., Kalaycığlu, H., and Hızıroğlu, S. (2013). "Effect of melamine impregnated paper on properties of oriented strand board," Mater. Des. 51, 751-755. DOI: $10.1016 /$ j.matdes.2013.04.052

Çavuş, V., and Mengeloğlu, F. (2016). "Utilization of synthetic based mineral filler in wood plastics composite," J. Achiev. Mater. Manuf. Eng. 77(2), 57-63. DOI: $10.5604 / 17348412.1230098$

Cavus, V. (2020). "Selected properties of mahogany wood flour filled polypropylene composites: The effect of maleic," BioResources 15(2), 2227-2236. DOI: 10.15376/biores. 15.2.2227-2236

Çetin, N. S., Özmen, N., Narlığlu, N., and Çavuş, V. (2014). "Effect of bark flour on the mechanical properties of HDPE composites," J. Mater. Sci. 1(3), 23-32. DOI: 10.12748/uujms.201416497

El-Shekeil, Y. A., Sapuan, S. M., Abdan, K., and Zainudin, E. S. (2012). "Influence of fiber content on the mechanical and thermal properties of kenaf fiber reinforced thermoplastic polyurethane composites," Mater. Des. 40, 299-303. DOI: 10.1016/j.matdes.2012.04.003

Karakuş, K., and Mengeloğlu, F. (2016). "Polycaprolactone (PCL) based polymer composites filled wheat straw flour," Kastamonu University Journal of Forestry Faculty 16(1), 264-268.

Lee, P. W., and Kim, C. S. (1985). "Bending strength of veneered particleboard composite with variations in shelling ratio and veneer grain angle," Wood Sci. Technol. 13(6), 23-25. DOI:

Li, Q., and Matuana, L. M. (2003). "Effectiveness of maleated and acryclic acidfunctionalized polyolefin coupling agents for HDPE-woodflour composites," $J$. Thermoplast. Compos. 16(6), 551-564. DOI: 10.1177/089270503033340

Liu, Y., and Zhu, X. (2014). "Measurement of formaldehyde and VOCs emissions from wood-based panels with nanomaterial added melamine impregnated paper," Constr. Build. Mater. 66, 132-137. DOI: 10.1016/j.conbuildmat.2014.05.088

Matuana, L. M., and Balatinecz, J. J. (1998). "Effect of surface properties on the adhesion between PVC and wood veneer laminates," Polym. Eng. Sci. 38(5), 765-773. DOI: 10.1002/pen.10242

Matuana, L. M., Park, C. P., and Balatinecz, J. J. (1998). “Cell morphology and property relationships of microcellular foamed PVC/wood-fiber composites," Polym. Eng. Sci. 38(1), 1862-1872. DOI: 10.1002/pen.10356

Mengeloglu, F., and Matuana, L. M. (2003). "Mechanical properties of extrusion foamed rigid PVC/wood-flour composites," J. Vinyl. Addit. Technol. 9(1), 26-31. DOI: $10.1002 / \mathrm{vnl} .10058$ 
Mengeloğlu, F., and Karakus, K. (2008). "Some properties of eucalyptus wood flour filled recycled high density polyethylene polymer-composites," Turk. J. Agric. For. 32(6), 537-546. DOI:

Mengeloglu, F., Kurt, R., Gardner, D. J., and O’neill, S. (2007). “Mechanical properties of extruded high-density polyethylene (HDPE)- and polypropylene (PP)- wood flour decking boards," Iran. Polym. J. 16(7), 477-487. DOI:

Mengeloglu, F., Bozkurt, F., Başboğa, I. H., and Yüce, Ö. (2015). "Waste melamine impregnated paper (MIP) in thermoset and thermoplastic based composites," ProLigno 11(4), 165-172. DOI:

Mengeloğlu, F., and Çavuş, V. (2019). "Additives used in wood plastic composite manufacturing" in: Research and Reviews in Agriculture, Forestry and Aquaculture Sciences, Gece Publishing, New York, NY, USA, pp. 49-58.

Nemli, G. (2000). Effects of Surface Coating Materials and Process Parameters on Technical Properties of Particleboard, Ph.D. Dissertation, Karadeniz Technical University, Trabzon, Turkey.

Nemli, G., and Çolakoğlu, G. (2005). "The influence of lamination technique on the properties of particleboard," Building and Environment 40(1), 83-87. DOI: 10.1016/j.buildenv.2004.05.007

Nemli, G., Y1ldız, S., and Gezer, E. D. (2005a). "Effects of melamine raw paper weight, varnish type, and the structure of continuous pressed laminate (CPL) on the physical, mechanical and decay resistance of particleboard," Int. Biodeter. Biodegr. 56(3), 166172. DOI: 10.1016/j.ibiod.2005.07.002

Özmen, N., Çetin, N. S., Narlığlu, N., Çavuş, V., and Altuntaş, E. (2014). "Utilisation of MDF waste for wood plastic composites production," University of Süleyman Demirel Faculty of Forestry Journal 15, 65-71. DOI: 10.18182/tjf.64025

Poletto, M. (2017). "Polypropylene-based wood-plastic composites: Effect of using a coupling agent derived from a renewable resource," Maderas. Ciencia y Tecnología 19(3), 265-272. DOI: 10.4067/S0718-221X2017005000022

Stokke, D. D., Wu, Q. L., and Han, G. P. (2014). Introduction to Wood and Natural Fiber Composites, John Wiley \& Sons, Chichester, England.

Varga, M., Alpar, T. L., and Nemeth, G. (2004). "General waste handling and recycling in particleboard production," Management of Environmental Quality an International Journal 15(5), 509-520. DOI: 10.1108/14777830410553951

Wang, S. Y., Yang, T. H., Lin, L. T., Lin, C. J., and Tsai, M. J. (2007). "Properties of low formaldehyde emission particleboard made from recycled wood-waste chips sprayed with PMDI/PF resin," Build. Environ. 42(7), 2472-2479. DOI: 10.1016/j.buildenv.2006.06.009

Article submitted: January 5, 2021; Peer review completed: February 28, 2021; Revised version received and accepted: March 5, 2021; Published: March 9, 2021.

DOI: $10.15376 /$ biores.16.2.3159-3170 